AGH DRILLING, OIL, GAS • Vol. 32 • No. $2 \cdot 2015$

http://dx.doi.org/10.7494/drill.2015.32.2.255

Cristian Gustavo Freidenberger*, Tomasz Śliwa**

\title{
RESIDENTIAL PRICE OF NATURAL GAS \\ IN ARGENTINA
}

\section{INTRODUCTION}

In the last years Argentina migrated from a self-supplied and exporter country of natural gas to an importer. Importation is primordial to ensure the internal provision in order to supply gas to a very gas dependent country. On the other hand argentine consumption has increased in the last years because of the economic growth.

Productive basins in Argentine Republic (Fig. 1) are far from consumption sectors. Main cities of consumption are the capital city, Buenos Aires and its metropolitan area. Third part of the population of Argentina lives in the capital city. Industry is the largest consuming sector.

Argentina is located third in Latin America respecting to natural gas reserves, after Venezuela and Bolivia.

The purpose of this article is to define the national framework of Argentina and also the price determination of natural gas for residential customers.

It is noted that natural gas wellhead price and the available in the residential sector, is low in comparison with other countries. Moreover transport distances to main consumption cities, make price of this commodity increase. On the other hand bigger prices of importation are subsidized by the government [1].

Argentina has changed its framework in 1992 but changes have been implemented several times [2].

* National Technological University, Bahía Blanca, Argentina, cristianfreidenberger@hotmail.com

** AGH University of Science and Technology, Faculty of Drilling, Oil and Gas, Krakow, Poland, sliwa@agh.edu.pl 


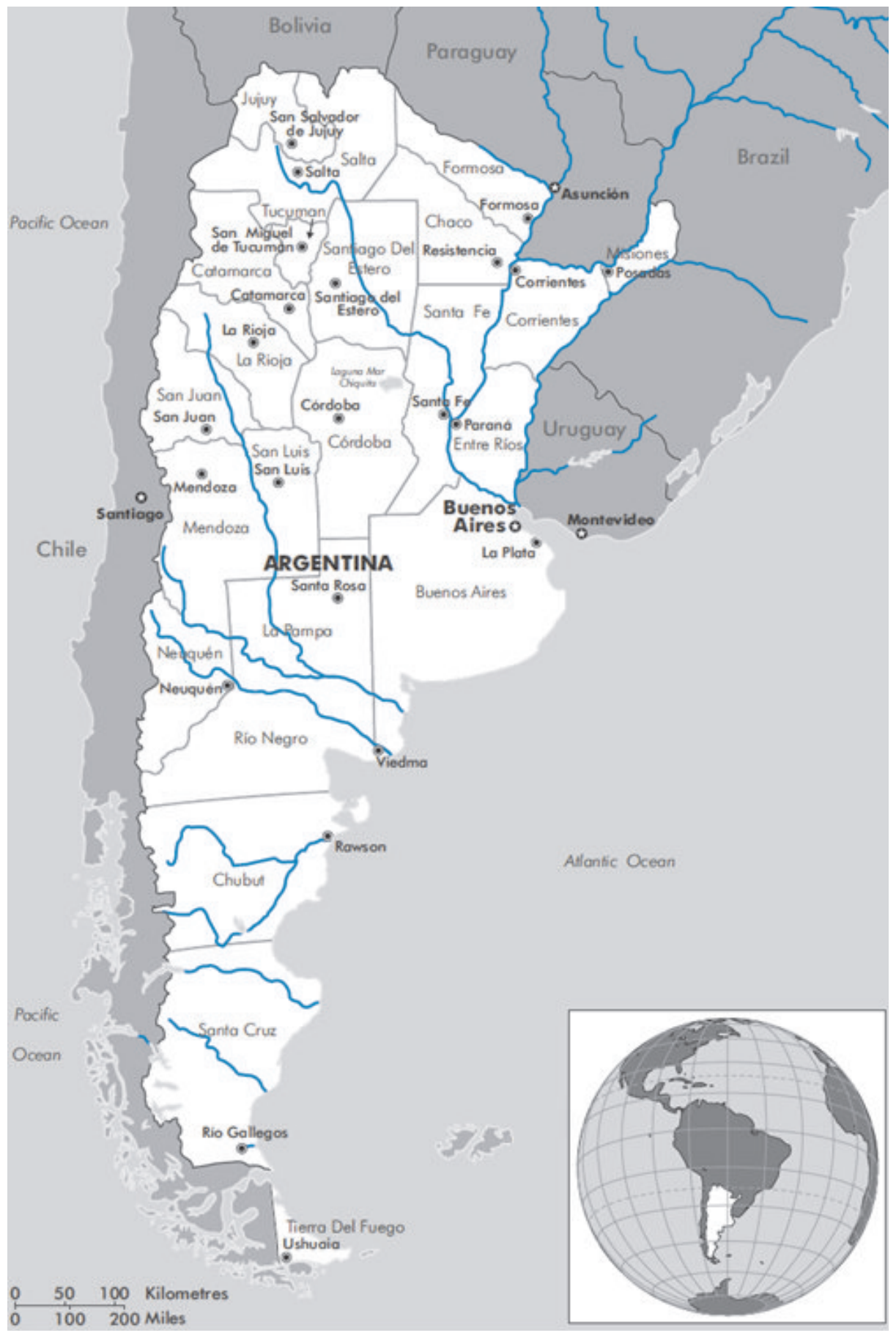

Fig. 1. Map of Argentina [3] 


\section{THE ROLE OF NATURAL GAS IN THE ENERGY MARKET}

Argentina has a very gas-intensive economy. The total primary energy supply of Argentina in 2011 was integrated $52.23 \%$ by natural gas (Tab. 1, Figs 2, 3). Most of the energy matrix is composed by fossil fuels. On the other hand renewable energies are extremely limited [4].

\section{Table 1}

Total primary energy supply of Argentina, based on [13]

\begin{tabular}{|l|c|c|}
\hline \multirow{2}{*}{ Source of energy } & \multicolumn{2}{c|}{ Total primary energy supply } \\
\cline { 2 - 3 } & {$[\mathrm{ktoe}]$} & {$[\%]$} \\
\hline Hydro & 3310.26 & 4.16 \\
\hline Nuclear & 2781.20 & 3.49 \\
\hline Natural Gas & 41607.91 & 52.23 \\
\hline Oil & 26461.37 & 33.22 \\
\hline Coal & 935.80 & 1.17 \\
\hline Wood & 644.58 & 0.81 \\
\hline Agricultural Waste & 962.61 & 1.21 \\
\hline Biofuel & 2552.30 & 3.20 \\
\hline Other & 409.57 & 0.51 \\
\hline TOTAL & 79665.61 & 100.00 \\
\hline
\end{tabular}

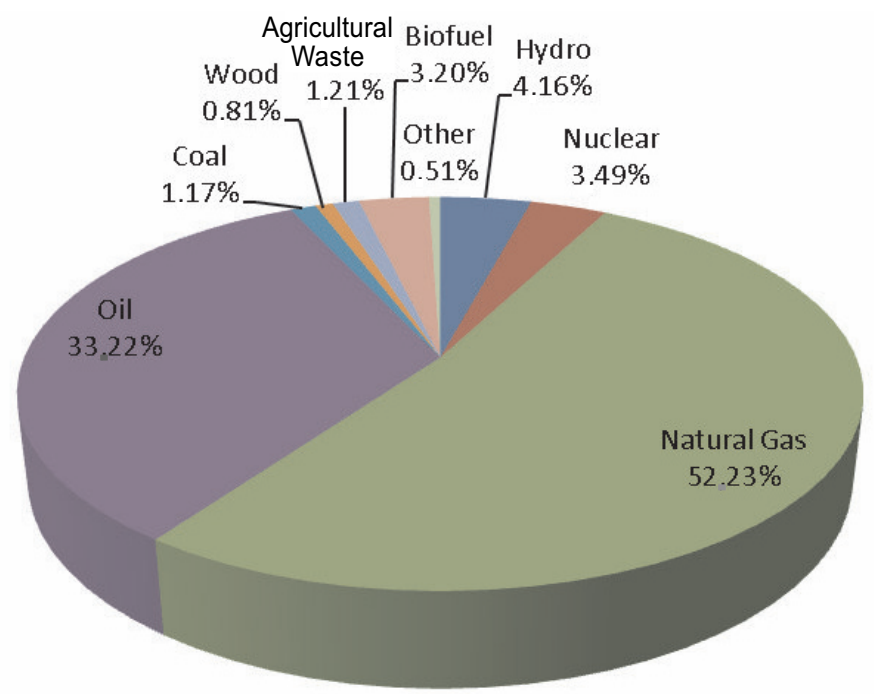

Fig. 2. Percentages of total primary energy supply, based on [13] 


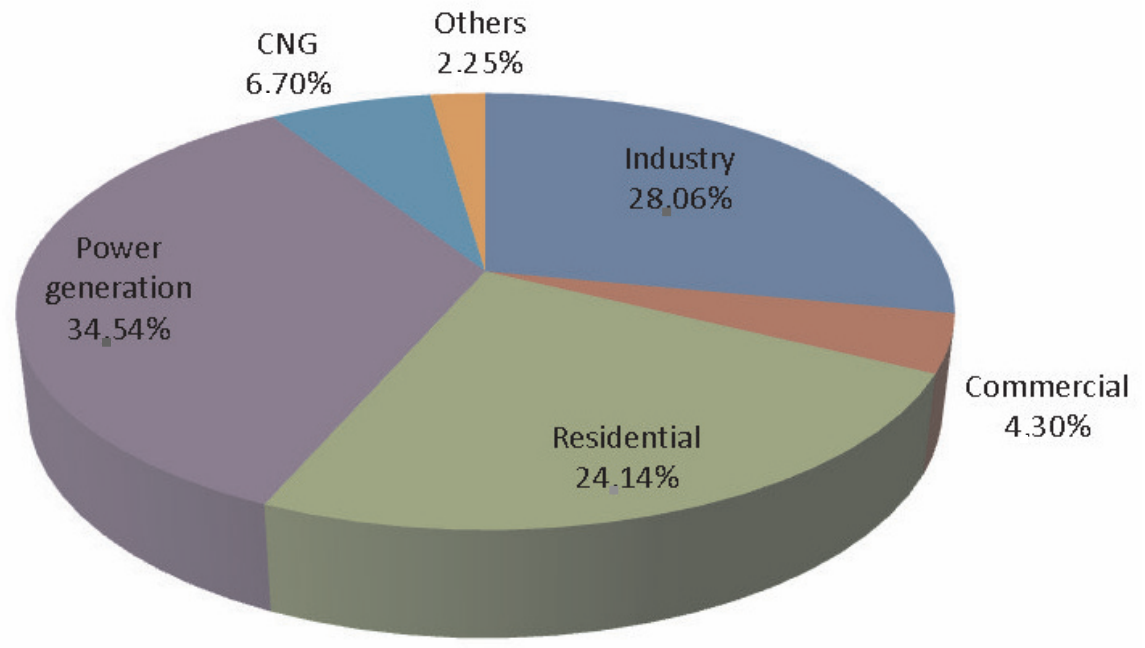

Fig. 3. Percentages of natural gas consumption by sector [13]

Use of gas has more than doubled since 1980. Gas consumed in Argentina is centred on the capital, Buenos Aires. Power plants consume the most important part of natural gas, it consumption is $34.54 \%$ of the total. Second and third are industrial consumption with $28.06 \%$ and residential demand with $24.14 \%$. Compressed natural gas (CNG) it largely used as vehicle fuel.

Gas demand in the residential sector is highly seasonal because it is used for space and water heating. Residential demand is five times higher in July than in January. Demand in the commercial sector, and to a much lesser extent in industry, is also sensitive to temperature. Power sector gas use is counter seasonal, peaking in the Southern Hemisphere summer (December to February). In the winter, generators switch away from interruptible gas to oil and coal, to conserve gas supplies for households and businesses [5].

\section{GAS MARKET STRUCTURE}

Wholesale market of natural gas in Argentina has three main parts, supply is developed by producers and importers.

On the other hand wholesale demand is required by distributors and big customers with consumption bigger than $5000 \mathrm{~m}^{3}$ of gas. This kind of large customers can buy this product direct from the producers. Distribution companies that serve the two different types of consumers usually subsidize free big customers in order to avoid defection of noncaptive customers to other suppliers. Customers with consumption smaller than $5000 \mathrm{~m}^{3}$ of gas are attended exclusively by distributors [16]. 
Finally, there are companies that work transporting gas from producers to distribution companies and large customers. Transmitters are not allowed to buy gas. This kind of company only works selling transmission services.

Distribution and transmission companies obtain licenses to operate for thirty five years with ten years of optional renewal. Licenses were given in 1992 due to the new gas framework [6].

\section{SUPPLY OF NATURAL GAS}

\section{Production}

There are nineteen known sedimentary basins in the country (Fig. 4), ten of which are located entirely onshore, three entirely offshore and six straddling the Atlantic coastline. Production is currently limited to five basins and three regions: Noroeste in Northern Argentina; Neuquina and Cuyana in Central Argentina; and Golfo San Jorge and Austral in Southern Argentina (Tab. 2).

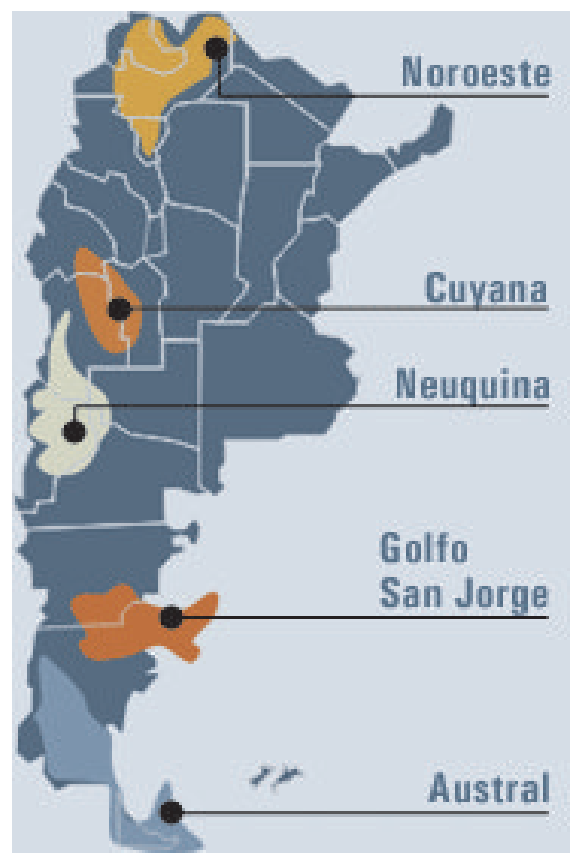

Fig. 4. Producing basins in Argentina [10]

The most important is Neuquina basin with $54.07 \%$ of national production and $44.1 \%$ of total reserves (Tab. 2, Fig. 5) [10]. 
Table 2

Production and reserves by basin in 2012 [10]

\begin{tabular}{|l|c|c|}
\hline \multicolumn{3}{|c|}{ Production and reserves in 2012} \\
{$[\mathrm{bcm}]$}
\end{tabular}

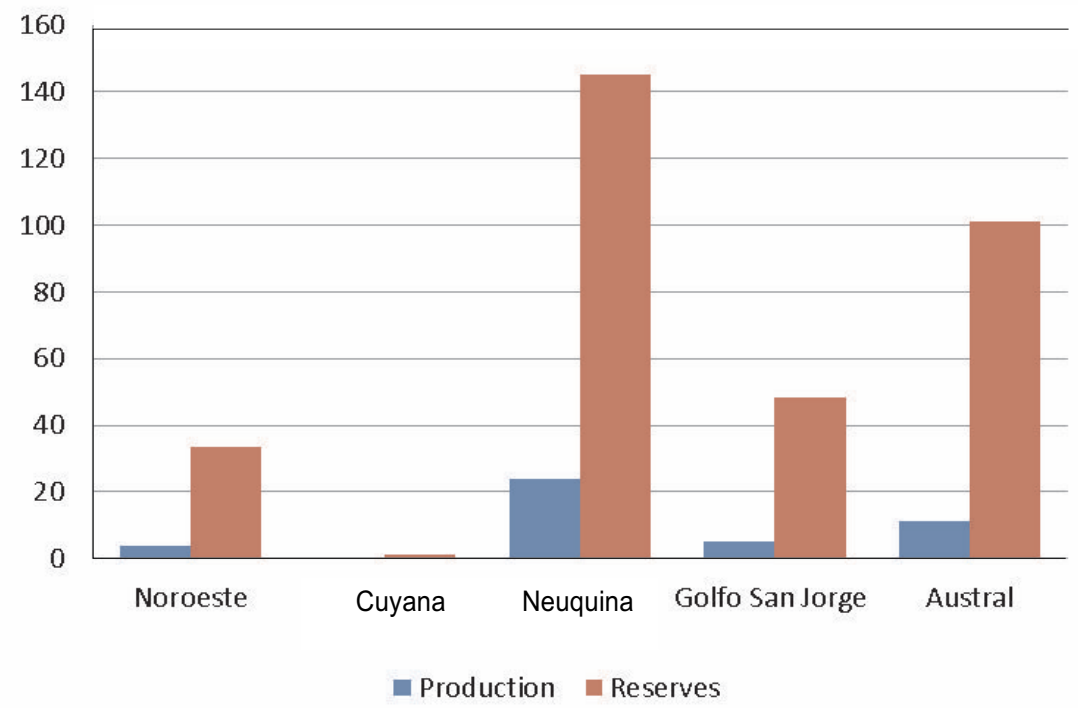

Fig. 5. Comparison of production and reserves by basin [bcm] [10]

Most of Argentina's gas reserves have been discovered as a result of oil exploration. These basins account for around a third of the total acreage of known sedimentary basins. In total, remaining reserves are equivalent to twenty years at current production levels. There is a considerable potential for additional gas reserves given that there are fourteen sedimentary basins that have not yet been explored.

Around twenty companies are extracting gas as producers. The most important producing companies are Yacimientos Petrolíferos Fiscales (YPF), Pecom, Petrobras, Pan American Energy, Total and Techint [7]. 
Table 3

Annual evolution of production [10]

\begin{tabular}{|c|c|c|c|}
\hline \multicolumn{4}{|c|}{$\begin{array}{c}\text { Annual evolution } \\
{[\mathrm{bcm}]}\end{array}$} \\
\hline year & production & year & production \\
\hline 2001 & 45.97 & 2007 & 51.01 \\
\hline 2002 & 45.87 & 2008 & 50.51 \\
\hline 2003 & 50.69 & 2009 & 48.42 \\
\hline 2004 & 52.38 & 2010 & 47.11 \\
\hline 2005 & 51.57 & 2011 & 45.52 \\
\hline 2006 & 51.78 & 2012 & 44.12 \\
\hline
\end{tabular}

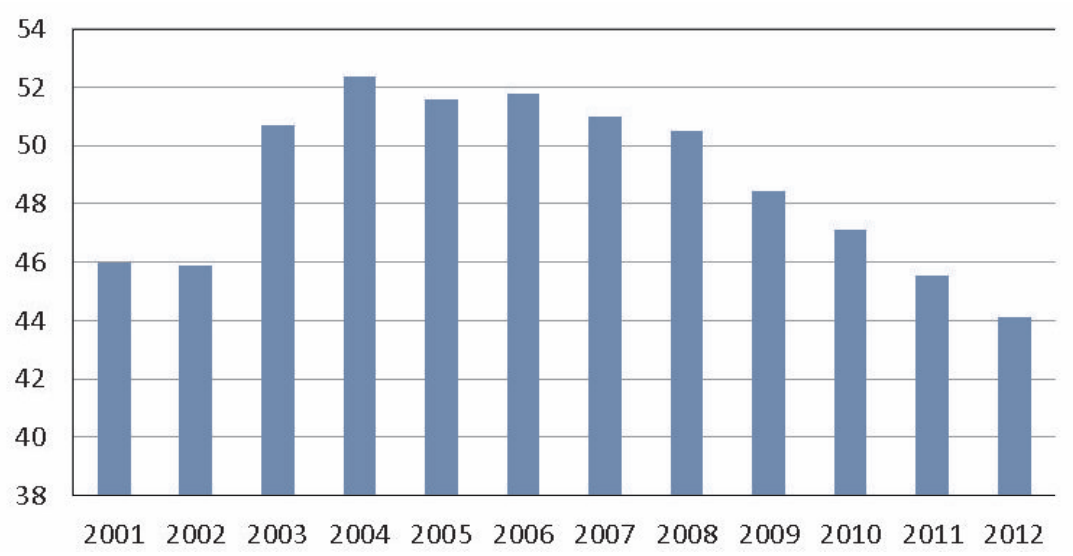

Fig. 6. Comparison of annual gas production [bcm] [10]

Argentina has lost its gas self-sufficiency in the last years. Natural gas production in Argentina has experienced a pronounced rise and fall separated by a peak in 2004 (Tab. 3, Fig. 6). Different hypothesis have been attempted to explain this phenomenon depending on the role attributed to firm behaviour on the one hand and the regulatory environment on the other. To some observers, the culprit of the fall in production since 2004 is explained by the lack of investment efforts by large firms and the fall of reserves or gas price aggravated by local politics [8].

\section{Imports and exports}

Historically the country ensured its self-supply, but in the last years gas import has increased, particularly to answer to the increment of internal demand and falling production (Tab. 4, Fig. 7). On the other hand gas exports require a special permission from the government. 
Table 4

Imports and 1exports of gas [10]

\begin{tabular}{|c|c|c|c|c|c|}
\hline Year & Imports & Exports & Year & Imports & Exports \\
\hline \multicolumn{3}{|c|}{$[\mathrm{bcm}]$} & \multicolumn{3}{|c|}{$[\mathrm{bcm}]$} \\
\hline 2001 & - & 6.05 & 2007 & 1.76 & 2.66 \\
\hline 2002 & - & 5.85 & 2008 & 1.45 & 1.01 \\
\hline 2003 & - & 6.46 & 2009 & 2.67 & 0.88 \\
\hline 2004 & 0.79 & 7.35 & 2010 & 3.61 & 0.46 \\
\hline 2005 & 1.73 & 6.6 & 2011 & 6.91 & 0.2 \\
\hline 2006 & 1.67 & 6.3 & 2012 & 9.51 & 0.1 \\
\hline
\end{tabular}

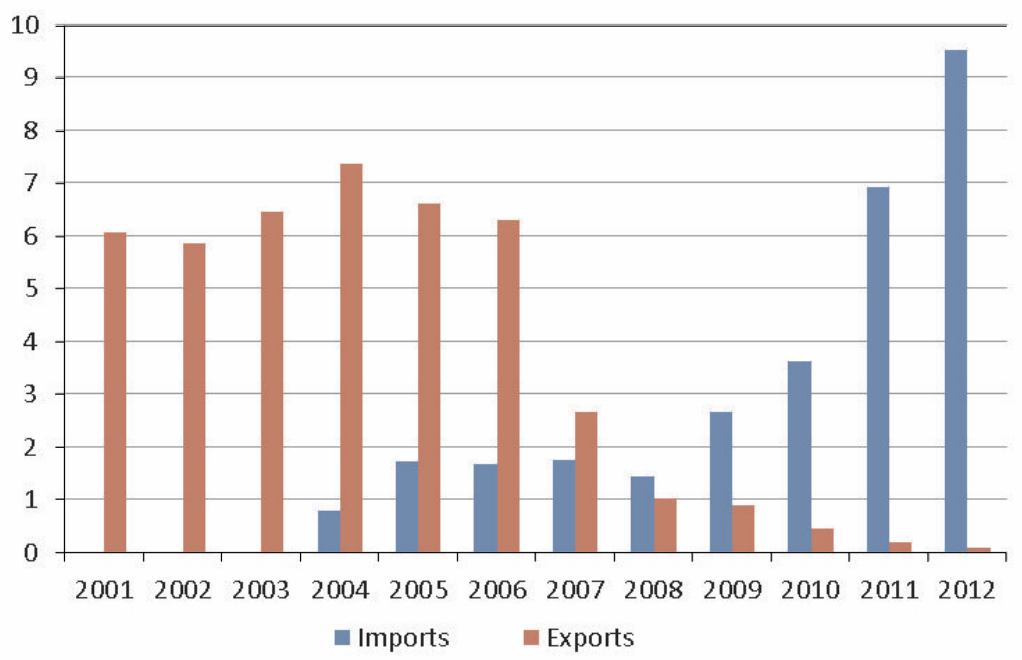

Fig. 7. Evolution of imports and exports [bcm] [10]

In addition, export pipelines have been developed to connect with new markets in Chile, Brazil, Bolivia and Uruguay [9].

Imported gas comes from Bolivia and its price in the fourth trimester of 2013 was 10.11 USD/MMBTU. Moreover is being exported liquefied natural gas that access through Bahía Blanca port and Escobar port, mainly coming from Trinidad and Tobago. Liquefied gas imports cost 17.5 USD/MMBTU. Argentina pays seven times the price of natural gas for liquefied natural gas purchases [12].

\section{Transmission}

Transmitters only sell transport services, they are not allowed to buy and sell natural gas, but they can purchase natural gas for own consumption. 
The national transmission network comprises five high-pressure pipeline systems, three of which bring gas from the Neuquina and Cuyana Basins in the West while the other two connect the Austral Basin in the South and the Noroeste Basin in the North. All five systems link into the Greater Buenos Aires market [11].

All pipes are divided to operate by two companies. Transportadora de Gas del Norte (TGN) has two pipelines and Transportadora de Gas del Sur (TGS) has three pipelines in operation.

\section{Distribution}

Distribution companies in order to supply their own markets, sign contracts with producers and hire transport capacity with transmission companies (Fig. 8).

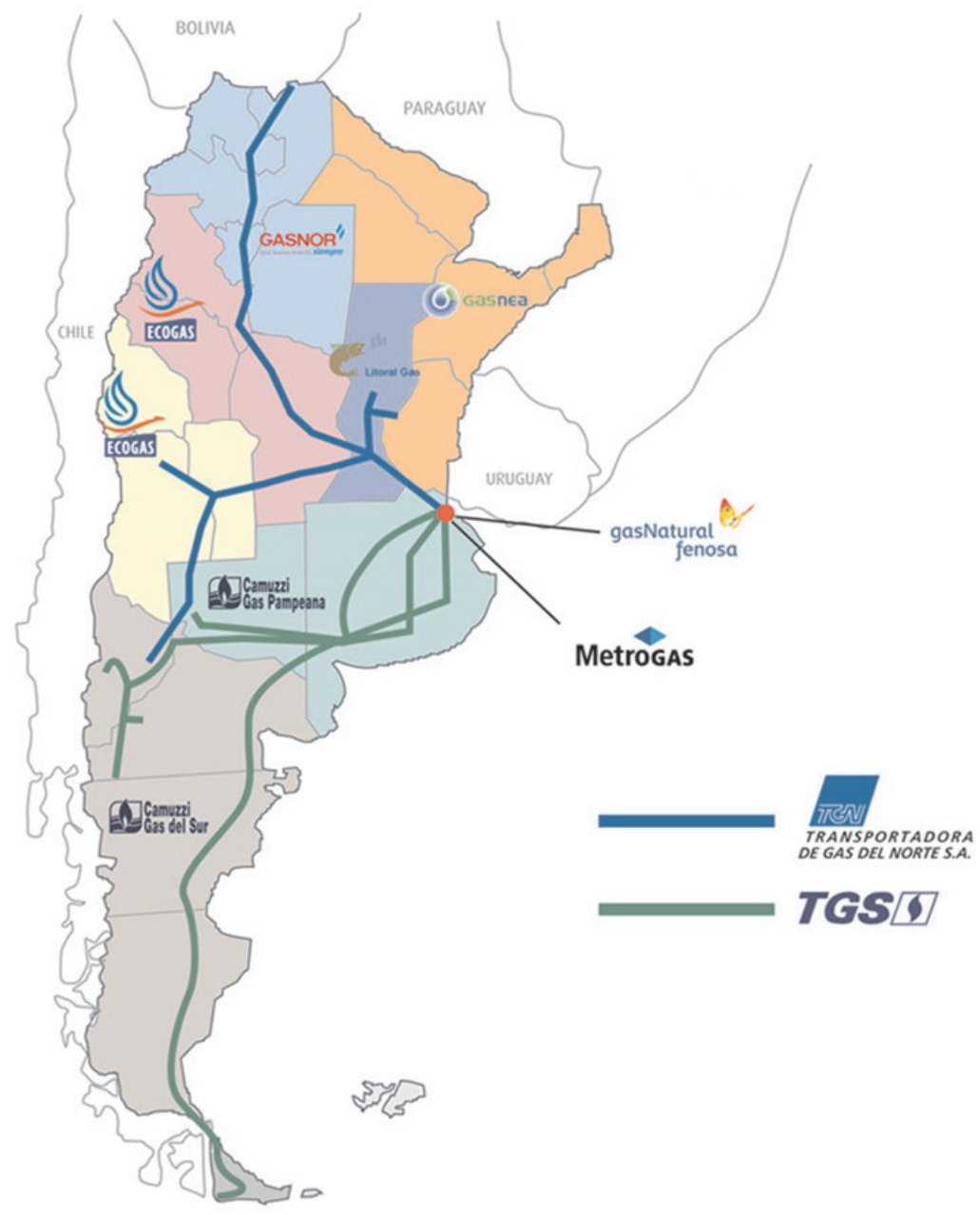

Fig. 8. Transmission system and distribution companies by geographical area [15] 
There are currently nine licensee companies for natural gas distribution networks. The geographical market is divided by nine business areas, one for each company. These companies distribute approximately $24.6 \mathrm{bcm}$ to ten million households, representing $55 \%$ of natural gas production. Almost $40 \%$ of the gas is consumed in the capital city, Buenos Aires [14].

\section{REGULATORY FRAMEWORK OF NATURAL GAS}

The gas regulatory framework introduced by Act 24.076, enacted in 1992, introduced significant changes to the way that historically the gas sector worked. One of the most important alterations was the vertical and horizontal disintegration of the state-owned company Gas del Estado (GDE), which had provided transmission and distribution of natural gas services as a monopoly between 1946 and 1992. This company was divided and privatized in two transmission companies and nine distribution companies with different geographical areas of operation, establishing restrictions on vertical integration. In this way transmission tariff and final price of distribution had been regulated by the government.

Moreover the national regulation entity ENARGAS was created to regulate transmission and distribution system and its price and taxes. The final customer price is defined as the addition of price at entry point into the transmission system (wellhead price), transmission tariff and distribution tariff. ENARGAS would be responsible for defining the transmission and distribution rates every five years.

Between 1922 and 1992, before implementation of new framework, production was monopolized by the government-owned corporation Yacimientos Petrolíferos Fiscales (YPF). The legal and fiscal framework for upstream activities in Argentina is the Law 17.319 of 1967 and subsequent associated decrees. Several decrees since 1989 have sought to minimise regulation of upstream activities to encourage exploration and production. These decrees have removed restrictions on imports of oil and gas, eliminated wellhead price controls, obliged YPF to surrender production interests and removed the company's exclusive rights over exploration and production. The Government has also taken steps to encourage foreign investment in the upstream and downstream oil and gas sectors and to reduce taxation and royalties. Framework allows imports of natural gas, but exports need a special permission from the state since 2004. Yacimientos Petrolíferos Fiscales (YPF) was privatized in 1999 but again nationalized in 2012 [17].

Another important modification introduced by the last framework is the relationship between transmitters, distributors and gas producers (Fig. 9). In the last framework before change, upstream price was regulated officially by secretariat of energy. After sanction of new legal structure in 1992, wellhead natural gas price was defined by the interaction of offer and demand, in a non-regulated market. During the first year of activity of transmission and distribution companies, gas price at entry point into the transmission system (wellhead price), which is included in final price to be paid by small and medium customers, was determined by the Ministry of Economy, Public Works and Services. Since January 1994 natural gas wellhead price began to be determined by a free market. As a result of this transition a new wholesaler market was born, whose principal actors were producers, 
transmission companies, big customers and distribution companies. But recently the decree 181 in 2004, established that price of natural gas at entry point into the transmission system should be defined by agreements between secretariat of energy and producing companies, so in the present this price is regulated by national government in consensus with gas producers.

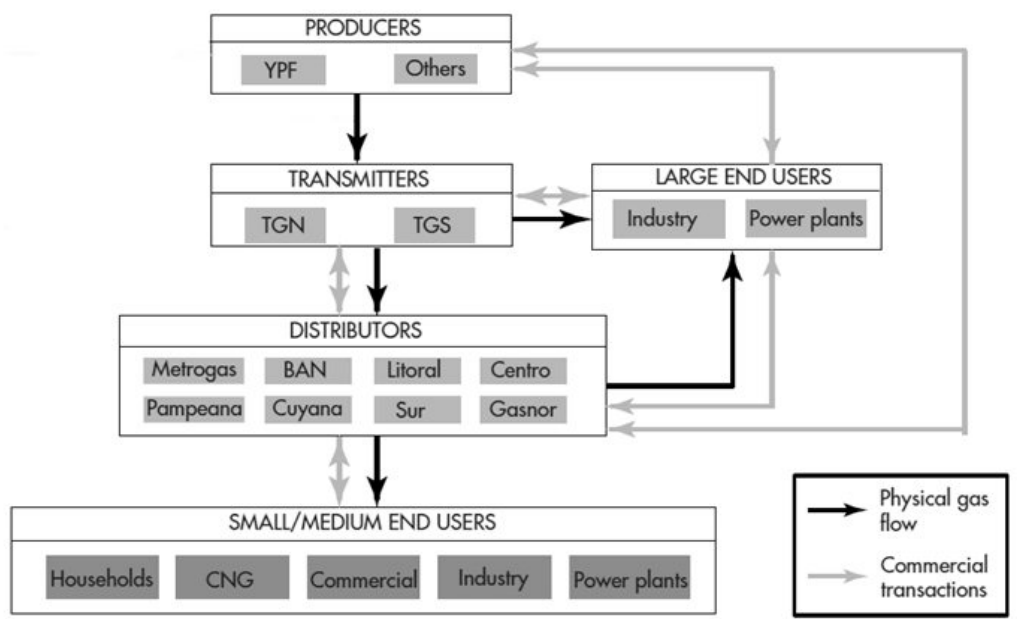

Fig. 9. Natural gas framework [3]

\section{ROLE OF ENARGAS}

ENARGAS, established under the 1992 Natural Gas Act, is an autonomous entity responsible for regulating the gas downstream industry under the Act, associated decrees and licenses. ENARGAS is governed by a board of five full-time directors appointed by the Federal Government. It operates within the framework of the Ministry of Economy, Public Works and Services and has broad authority to regulate the operations of the transmission and distribution companies, including setting rates.

ENARGAS has its own budget, which is included in the Argentine National Budget. Funding is derived largely from control and inspection fees levied on the regulated companies and allocated proportionately to each company based on their gross revenues from regulated activities. ENARGAS also collects any fines imposed for violations of the Natural Gas Act and company licences [19].

ENARGAS's objectives, set out in the 1992 Act, include:

- Protecting consumer interests.

- Promoting competition in gas supply.

- Encouraging long-term investment in the network.

- Setting just and reasonable tariffs for transmission and distribution.

- Ensuring there is no discrimination in the provision of transmission and distribution services. 


\section{SETTING OF TRANSMISSION AND DISTRIBUTION TARIFF}

Gas transmission and distribution is regulated by ENARGAS. The framework of 1992 allows all stakeholders of the systems ask for price readjustment. Tariffs should be determined by ENARGAS in order to compensate provision cost and adding an extra resource of benefit for the company according to business risks. Additionally company efficiency providing the service is taken into account to set tariff [21].

The Gas Act of 1992 developed a system of adjustment for prices in order to inflation, company efficiency and investment factor. This adjustment had to be determined every five years but Economic Emergency Act suspended second five-year review in 2002 and ENARGAS adopted provisional rates:

- Inflation: After reform of framework, companies was allowed to adjust their tariffs every six months to reflect inflation as measured by changes in the US producer price index of industrial commodities (PPI), but in 2002 Economic Emergency Act freezes the rates that companies could charge for gas transmission and distribution, replacing the semi-annual adjustment for inflation. In this way distribution and transmission tariffs are almost frozen since 2002.

- Efficiency (x) factor: This factor, reviewed every five years, provides for a reduction in tariffs as costs are reduced through improved efficiency, allowing the company and customers to share in the gains. The company is given an incentive to lower costs because the factor and the tariffs based on it are established five years in advance. The factor is derived from estimated cost savings potential and is not adjusted during the five year period according to actual cost savings.

- Investment (k) factor: This factor is reviewed also every five years in concordance with efficiency factor. It is an increment in tariffs to compensate companies because of cost of investment that companies are going to make in the future. It includes investments to increase efficiency, security, reliability and expansion of the system. ENARGAS should recommend companies with investments that they must make to increase factor. Companies are not obligated to proceed but it will increase the tariff.

The approval of the Economic Emergency Act was enacted in order to protect customers from an accelerated devaluation that Argentine Peso was suffering. Previously distribution and transmission tariff was determined in American Dollars and then transformed to the argentine national currency but after Emergency Act this fares were changed to peso. Otherwise the devaluation of the peso and service rates determined in dollars would generate a significant rise in gas price for residential customers [22].

\section{ECONOMIC EMERGENCY ACT}

The Emergency Act authorizes the National Executive Power among other things, to rescind the adjustment of price according to indexes of other countries contained in the concession contracts of public services, also authorizes the Executive Power to renegotiate license granted by the Federal Government for the provision of public services. 
The validity of the law was extended by other acts, the last extension was Act 26.896 which extends term to December 31, 2015 [23].

The main effects on natural gas framework by Emergency Law are listed following:

- Dollar rates updated by PPI: The Emergency Law forbade adjustment clauses for price according to indexes of other countries in the concessions or licenses.

- Second quinquennial review: Following the enactment of the Emergency Law, ENARGAS ordered the suspension of the second five-year review of rates. Provisional tariffs were approved.

- Tariffs: Emergency Act authorizes the government to negotiate contracts and rates with licensees of public services.

After Economic Emergency Act enactment, transmission and distribution tariffs have been mostly frozen or affected by a small increment, but liabilities of different companies have been increased highly. Final price of gas has increased only by changes in the wellhead price agreed by the Secretary of Energy and producers and imported gas price.

\section{RESIDENTIAL CONSUMPTION CATEGORIES}

Natural Gas Act determined eight different categories for residential customers divided by range of consumption. This categorization is done considering the consumption of the current bimonthly period and five immediately preceding periods, that is why the category is mobile.

Consumption rates have different limits in different areas of the country in order to show relevant differences in consumption. The lowest category is R1 [24].

\section{PRICE OF RESIDENTIAL GAS}

Invoicing in Argentine residential sector is delivered bimonthly. ENARGAS submit tables with final price for different categories. The final customer price of gas is the result of the addition of the following prices:

- Gas wellhead price:

- Gas price at entry point into the transmission system: This was the price that distribution companies hired with production companies in a free market, but with the enactment of decree 181 in 2004 it changed and in the present the energy secretariat determines the price agreeing with producers. Large residential customers pay bigger price for wellhead gas.

- Daily accumulated differences: The daily accumulated differences are a concept which is added or discounted to the gas price at entry point to make pass-through price coincident with real purchase price. For this purpose distribution company has an accounting of real purchase gas price separated by different producers and basins. Daily differences are accumulated monthly, adjusted by an interest rate and then added or discounted. 
- Retained gas cost: Part of the gas that is injected into the pipeline system is consumed as fuel for compressors involved in the transport from the basin. This consumption is a percentage of total gas by pipeline and by distribution company.

- Transmission tariff: Transmission companies earn for transporting natural gas from entry point to transmission system to the operation zones of distribution companies. Customers pay the transmission tariff as a function of a factor assigned to that category of user. Transmission tariff comes from an average of transport cost in different pipelines used by the distribution company, weighted by the contracted capacity for such routes. The factor for different categories is a quotient between average daily consumption and peak in the last twelve months for a particular category. That represents an approximation of transmission demand needed to supply gas in peak consumption days.

- Distribution tariff: Distribution tariff is the remuneration for serving final customers and it is composed by a fixed charge and a variable cost as a function of consumption. Minimum invoice is also determined. All charges depend on different categories (Tab. 5). Following is shown a comparison of variable cost $\left(\mathrm{USD} / \mathrm{m}^{3}\right)$ of natural gas in Buenos Aires city through the years for the first consumption category (R1) (Tab. 6, Fig. 10). Gas variable cost has not changed since 2008, this year was the last revision, but between 2013 and 2008 the national currency has been strongly devalued [25].

Figure 10 shows how the natural gas price has lost its value due to the enactment of the Economic Emergency Act of 2002. The gas cost for residential customers has not changed since this year in argentine pesos but the national currency has a lower price in comparison with the American dollar. The national currency before the enactment of the Emergency Act was equal to the American dolar value, but in December of 2013 one dollar is equivalent to more than 6.5 Argentine pesos.

Table 5

Gas distribution tariff for residential customers [15]

\begin{tabular}{|c|c|c|c|}
\hline \multicolumn{4}{|c|}{ Final customer price (without taxes and charges) } \\
\hline & & minimum & maximum \\
\hline \multicolumn{2}{|c|}{ Fixed charge [USD] } & 1.181453 & 1.585609 \\
\hline \multicolumn{2}{|c|}{ Minimum invoice [USD] } & 1.535948 & 2.685702 \\
\hline \multirow{8}{*}{$\begin{array}{c}\text { Variable cost } \\
{\left[\mathrm{USD} / \mathrm{m}^{3}\right]}\end{array}$} & R1 & 0.011355 & 0.071595 \\
\hline & $\mathrm{R} 2-1^{\mathrm{o}}$ & 0.011355 & 0.071595 \\
\hline & $\mathrm{R} 2-2^{\mathrm{o}}$ & 0.011355 & 0.071595 \\
\hline & $\mathrm{R} 2-3^{\mathrm{o}}$ & 0.011642 & 0.074315 \\
\hline & R3 $-1^{o}$ & 0.016649 & 0.080760 \\
\hline & R3- $2^{\circ}$ & 0.016649 & 0.080760 \\
\hline & $\mathrm{R} 3-3^{\mathrm{o}}$ & 0.022427 & 0.088689 \\
\hline & R3 $-4^{\circ}$ & 0.022427 & 0.088689 \\
\hline
\end{tabular}




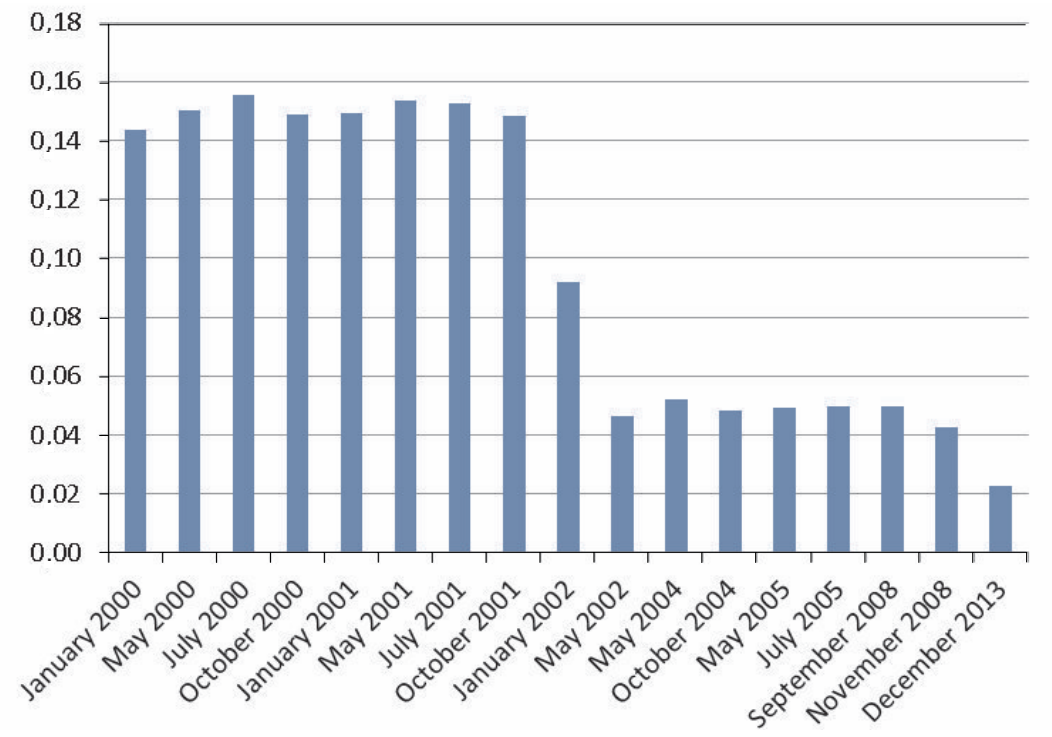

Fig. 10. Variation of gas price for residential customers during time in Buenos Aires City [15]

- Taxes and charges: There are different taxes and charges according with different geographical areas. Some of the most important taxes are developed following.

- VAT: The value added tax, with a tax rate of $21 \%$ applies to all billed items.

- Trust fund for imported gas: Promoted by presidential decree 2067 of 2008 to pay the imports of natural gas and ensure domestic supply. This charge is not paid by most of small customers because the National Government grants a subsidy to customers in categories R1 and R2. Big customers in category R3 are subsidized if they demonstrate inability to pay the cost of imported gas but the subsidy is not fully (Tabs 6 and 7).

Table 6

Trust fund for imported gas [18]

\begin{tabular}{|c|c|c|}
\hline \multicolumn{3}{|c|}{ Trust fund for imported gas } \\
\hline category & minimum & maximum \\
\hline R1 & 0.002 & 0.014 \\
\hline $\mathrm{R} 2-1^{\mathrm{o}}$ & 0.003 & 0.017 \\
\hline $\mathrm{R} 2-2^{\mathrm{o}}$ & 0.003 & 0.017 \\
\hline $\mathrm{R} 2-3^{\circ}$ & 0.003 & 0.021 \\
\hline $\mathrm{R} 3-1^{\mathrm{o}}$ & 0.004 & 0.027 \\
\hline $\mathrm{R} 3-2^{\mathrm{o}}$ & 0.011 & 0.074 \\
\hline $\mathrm{R} 3-3^{\mathrm{o}}$ & 0.015 & 0.104 \\
\hline $\mathrm{R} 3-4^{\mathrm{O}}$ & 0.027 & 0.148 \\
\hline
\end{tabular}


Table 7

Trust fund for imported gas for subsidized customers [20]

\begin{tabular}{|c|c|c|}
\hline \multicolumn{3}{|c|}{ Trust fund for imported gas } \\
\hline category & minimum & maximum \\
\hline R3-1 & 0.001 & 0.008 \\
\hline R3-2 $^{\circ}$ & 0.003 & 0.021 \\
\hline R3-3 $^{\circ}$ & 0.004 & 0.030 \\
\hline R3-4 & 0.008 & 0.148 \\
\hline
\end{tabular}

- FOCE: In 2012 it was imposed a special fixed amount by resolution 2407 of ENARGAS, differentiated by user category, exclusively for the execution of infrastructure works (Tab. 8).

Table 8

FOCE charge [31]

\begin{tabular}{|c|c|}
\hline \multicolumn{2}{|c|}{ Foce } \\
{$[$ ARS $]$} \\
\hline $\mathrm{R} 1$ & 4.00 \\
\hline $\mathrm{R} 2-1^{\circ}$ & 5.00 \\
\hline $\mathrm{R}^{\mathrm{O}}-2^{\mathrm{o}}$ & 6.50 \\
\hline $\mathrm{R} 2-3^{\mathrm{o}}$ & 8.50 \\
\hline $\mathrm{R} 3-1^{\mathrm{o}}$ & 15.00 \\
\hline $\mathrm{R} 3-2^{\circ}$ & 20.00 \\
\hline $\mathrm{R} 3-3^{\circ}$ & 30.00 \\
\hline $\mathrm{R} 3-4^{\circ}$ & 60.00 \\
\hline
\end{tabular}

- Act 25.413: Tax on debits and credits in bank account. The fee is calculated based on the total computable tax paid by the Distributor plus the value invoiced by the distribution company. This amount is transferred to all customers based on the total invoice and included in the invoice issued three months later.

It is allowed to create different taxes by national and provincial government and the city hall. The tax charge is significant in natural gas invoice, it ascend to $50 \%$ of the bill in some geographical areas. 


\section{CONCLUSIONS}

1. Natural Gas Act 24.076, enacted in 1992, disposed privatization of the monopoly Gas del Estado (GDE), regulatory framework for distribution and transmission of gas, creation of regulation entity ENARGAS and the alienation of Yacimientos Petroliferos Fiscales (YPF).

2. In the beginning of 2002 Emergency Act 25.561 was enacted. Alteration of contracts connected to the devaluation of the Argentine peso and rates freeze occurred. This law was successfully to protect customers from the highly devaluation of the national currency, but was largely extended in time. Before the implementation of this law conversion was one Argentine peso equals to one American dollar because of Convertibility Act. Under this context tariffs were frozen. But in December of 2013 the conversion was 6.40 Argentine pesos equals to one American dollar. In this way, natural gas price in Argentina is extremely retarded within the international context. Natural gas has only increased by changes in wellhead price or import price, but it has not increased because of changes in transmission and distribution tariffs, except for small adjustments for renegotiation of contracts.

3. According to national statistics, salary index in private sector has increased $388 \%$ and customer price index growth $166 \%$ between 2001 and 2012. Thus natural gas prices do not reflect the new context in the country.

4. Despite of small distribution and transmission tariffs, regulated sector subsists primarily due to exploitation of infrastructure and incorporating new customers. However, the possibility to continue using the existing infrastructure is reaching its limit and is essential a readjustment of tariffs.

5. Reserves in upstream activities framework are going down continuously and this is endangering provision from own deposits. Besides wellhead price of gas does not encourage new investments in non-explored basins.

6. Since 2008 the implementation of Decree 2067 incorporated a trust fund to pay the cost of imported natural gas, increasing the price to the end customer powerfully. Although to date, this cost has not been transferred to final consumers, otherwise is mostly paid by the state. On the other hand this growth is not an increase for downstream companies or producers.

7. In this context, price in the national gas market require a long-term and secure legal framework for investment and development.

\section{REFERENCES}

Following references were accessed in December 2013.

[1] Bondorevsky D., Petrecolla D.: Estructura del mercado de gas natural en argentina e integración energética regional. Available in: http://www.uade.edu.ar/DocsDownload/Publicaciones/4_226_1580_STD029_2001.pdf. 
[2] Conticello T., Liotta H., Salvá G., Maimbil E.H., Romera N.H.: Gas Production Model in Argentina. Available in:

http://www.dinamica-de-sistemas.com/revista/0613i-dinamica-de-sistemas.pdf.

[3] Priddle R.: Regulatory reform in Argentina's natural gas sector.

Available in: http://fracking.cedha.net/wp-content/uploads/2013/08/Regulatory-Reformin-Argentinas-Natural-Gas-Sector.pdf.

[4] Apud E., Araoz J.C., Devoto E., Echarte R., Guadagni A., Lapeńa J., Montamat D., Olocco R.: La caída de las reservas de hidrocarburos el problema más importante del sector energético argentino.

Available in: http://iae.org.ar/DECLARACION_EX_SECRETARIOS_RESERVAS\%20 HIDROCARBUROS_MAYO2011.pdf.

[5] Barril D., Navajas F.: What drove down natural gas production in Argentina? Available in: http://www.ucema.edu.ar/conferencias/download/2011/06.24AE.pdf.

[6] Oszlak O., Felder R., Forcinito K.: La capacidad regulatoria del estado en argentina. Available in: http://catedras.fcp.uncu.edu.ar/claroline/backends/download.php?url= L09TWkxBSyxfRkVMREVSLF9GT1JDSU5JVE9fLV9MYV9jYXBhY2lkYWRfcm VndWxhdG9yaWFfZGVsX2VzdGFkb19lb19hcmdlbnRpbmEucGRm\&cidReset=true\& cidReq=OYG.

[7] Kozulj R.: Análisis de formación de precios y tarifas de gas natural en América del Sur. Available in: http://www.iadb.org/intal/intalcdi/PE/2012/10460.pdf.

[8] Los subsidios en argentina I - Marco General y Sector Energético.

Available in: http://www.paraelcambio.org.ar/contenido/dtrabajo/2009-03-dt31-subsidios-en-argentina.pdf.

[9] O'Keefe T.A.: The Crisis in the Argentine Natural Gas Sector and Its Impact on Regional Energy Integration.

Available in: https://csis.org/images/stories/Americas/070316_okeefe_argentina.pdf.

[10] Instituto Argentino del Petróleo y del Gas.

Available in: http://www.iapg.org.ar/estadisticasnew/.

[11] Gas Natural Fenosa: Available in: http://www.gasnaturalfenosa.com.ar.

[12] Hidrocarburos Bolivia. Available in: http://www.hidrocarburosbolivia.com.

[13] Energy balances of the Secretariat of Energy.

Available in: http://www.energia.gov.ar/contenidos/verpagina.php?idpagina=3366.

[14] Ecogas.

Available in: https://www.ecogas.com.ar/appweb/leo/inicio.php?sitio=cuyo_cuadros tarifarios.

[15] ENARGAS. Available in: http://www.enargas.gov.ar.

[16] Act 24.076. Available in: http://mepriv.mecon.gov.ar/Normas/24076.htm.

[17] Decree 181/2004. Available in: http://mepriv.mecon.gov.ar/Normas/181-04.htm.

[18] Decree 2067/2008.

Available in: http://www.gasnea.com.ar/decretos/FONDO\%20FIDU CIARIO\%20DEC _2067-08.pdf. 
[19] Resolution 409. ENARGAS.

Available in: http://www.enargas.gov.ar/MarcoLegal/Resoluciones/Data/R08_i0409.htm.

[20] Resolution 563. ENARGAS.

Available in: http://www.abastonet.com.ar/seccion\%20gas/RES_563.pdf.

[21] Resolution 566. ENARGAS.

Available in: http://www.enargas.gov.ar/_blank.php?iFrame=/MarcoLegal/Resoluciones/Data/R08_i0566.pdf.

[22] Resolution 567. ENARGAS.

Available in: http://www.enargas.gov.ar/_blank.php?iFrame=/MarcoLegal/Resoluciones/Data/R08_i0567.pdf.

[23] Resolution 568. ENARGAS.

Available in: http://www.enargas.gov.ar/_blank.php?iFrame=/MarcoLegal/Resoluciones/Data/R08_i0568.pdf.

[24] Resolution 569. ENARGAS.

Available in: http://www.enargas.gov.ar/_blank.php?iFrame=/MarcoLegal/Resoluciones/Data/R08_i0569.pdf.

[25] Resolution 570. ENARGAS.

Available in: http://www.enargas.gov.ar/_blank.php?iFrame=/MarcoLegal/Resoluciones/Data/R08_i0570.pdf.

[26] Resolution 571. ENARGAS.

Available in: http://www.enargas.gov.ar/_blank.php?iFrame=/MarcoLegal/Resoluciones/Data/R08_i0571.pdf.

[27] Resolution 572. ENARGAS.

Available in: http://www.enargas.gov.ar/_blank.php?iFrame=/MarcoLegal/Resoluciones/Data/R08_i0572.pdf.

[28] Resolution 573. ENARGAS.

Available in: http://www.enargas.gov.ar/_blank.php?iFrame=/MarcoLegal/Resoluciones/Data/R08_i0573.pdf.

[29] Resolution 577. ENARGAS.

Available in: http://www.enargas.gov.ar/_blank.php?iFrame=/MarcoLegal/Resoluciones/Data/R08_i0577.pdf.

[30] Resolution 1982. ENARGAS.

Available in: http://www.enargas.gov.ar/MarcoLegal/Resoluciones/Data/R11_i1982.htm.

[31] Resolution 24072. ENARGAS.

Available in: http://www.enargas.gov.ar/MarcoLegal/Resoluciones/Data/R12_i2407.htm.

\section{GLOSARY}

bcm - billion cubic meters $\left(1.000 .000 .000 \mathrm{~m}^{3}\right)$.

CNG - compressed natural gas.

ENARGAS - Ente Nacional Regulador del Gas (ang. National Gas Regulator Entity). 
FOCE - Fondo para Obras de Consolidación y Expansión (ang. Fund for works of consolidation and expansion).

GDE - Gas del Estado, former monopoly of gas transmission and distribution.

ktoe - thousand tonnes of oil equivalent.

PPI - Producer Price Index.

TGN - Transportadora de Gas del Norte, transmission company.

TGS - Transportadora de Gas del Sur, transmission company.

VAT - value added tax.

YPF - Yacimientos Petrolíferos Fiscales, former monopoly of gas production. 